\title{
BIOMECHANICAL ANALYSIS OF FEMORAL NECK FRACTURE FIXATION IN SYNTHETIC BONE
}

\section{ANÁLISE BIOMECÂNICA DA FIXAÇÃO DA FRATURA DO COLO DO FÊMUR EM OSSO SINTÉTICO}

\author{
Henrique Mansur ${ }^{1,2}$, Rafael Alvarez ${ }^{2}$, Anderson Freitas ${ }^{3}$, Cesar Barbosa Gonçalves ${ }^{4}$, Max Rogerio Freitas Ramos ${ }^{1}$ \\ 1. Universidade Federal do Estado do Rio de Janeiro, RJ, Brazil. \\ 2. Hospital de Força Aérea de Brasília, Brasília, DF, Brazil. \\ 3. Hospital Ortopédico e Medicina Especializada (HOME), Brasília, DF, Brazil. \\ 4. Hospital Naval Marcílio Dias, Rio de Janeiro, RJ, Brazil.
}

\section{ABSTRACT}

Objectives: To analyze the results of biomechanical assays of the fixation of Pauwels type II femoral neck fractures in synthetic bones, using two parallel cannulated screws or three cannulated screws in an inverted pyramid formation. Methods: Ten Brazilian-made synthetic bones were divided into 2 groups. Groups A and B utilized three and two cannulated screws, respectively, after osteotomy in the middle third of the femur, perpendicular to the axis of the femoral neck, simulating a Pauwels type II femoral neck fracture. The resistance of these fixations was analyzed by compression on the axis of the force resulting from hip compression, simulated with a manual hydraulic press. The T-test and post hoc analysis were used to compare the groups, and the significance criterion adopted was $p<0.05$. Results: In group $A$, which used fixation with three screws, synthesis failure was seen at a mean force of $526 \mathrm{~N}$. In group B, which used two screws, the mean force was $466 \mathrm{~N}$. The results presented a statistically significant difference $(p=0.02)$. Conclusion: The osteosynthesis of femoral neck fractures in synthetic bone fixated with two screws presented inferior results to fixation with three screws. Level of Evidence III; Case-control study.

Keywords: Bone screws. Femoral neck. Hip fractures.

\section{RESUMO}

Objetivos: analisar os resultados dos ensaios biomecânicos da fixação da fratura de colo de fêmur Pauwels tipo Il em ossos sintéticos, utilizando dois parafusos paralelos ou três parafusos em formação de triângulo invertido. Métodos: Foram utilizados 10 ossos sintéticos, de uma marca nacional, divididos em dois grupos. Nos grupos $A$ e $B$ foram realizados, respectivamente, fixação com três e com dois parafusos canulados, após osteotomia perpendicular ao colo femoral no seu terço médio, simulando uma fratura do colo femoral Pauwels tipo II. Analisou-se a resistência destas fixações a uma compressão no eixo da força resultante de compressão do quadril, através de uma prensa hidráulica manual. O teste te a análise "post hoc" foram utilizadas para comparação dos grupos e o critério de determinação de significância adotado foi $p<0,05$. Resultados: No grupo A, submetido à fixação com três parafusos, observou-se a falha da síntese com uma média de $526 \mathrm{~N}$. Já no grupo $B$, com dois parafusos, a média foi de $466 \mathrm{~N}$. Os resultados encontrados apresentaram diferença estatisticamente significativa, $\operatorname{com} p=0,02$. Conclusão: A osteossíntese das fraturas do colo femoral de osso sintético com dois parafusos apresentou resultados inferiores à utilização de três parafusos. Nível de Evidência III; Estudo caso-controle.

Descritores: Parafusos ósseos. Colo femural. Fraturas do quadril

Citation: Mansur H, Alvarez R, Freitas A, Gonçalves CB, Ramos MRF. Biomechanical analysis of femoral neck fracture fixation in synthetic bone. Acta Ortop Bras. [online]. 2018;26(3):162-5. Available from URL: http://www.scielo.br/aob.

\section{INTRODUCTION}

Fractures in the proximal third of the femur cause high morbidity and mortality, with many patients dying within two years. Femoral neck fractures are frequently seen in clinical practice, representing $40-50 \%$ of proximal femur fractures. ${ }^{1,2}$ The average age of patients with these fractures is 75-80 years for women, and slightly lower in men. They commonly occur in patients with multiple comorbidities, and represent high costs for treatment and management. ${ }^{3-5}$

Pauwels classification divides femur neck fractures into three types based on the angle that the fracture forms with the horizontal plane.
In type I fractures this angle is $30^{\circ}$, in type $\| 50^{\circ}$, and in type III $70^{\circ}$. As the fracture becomes more oblique instability also increases, and complications related to fixation and consolidation worsen. ${ }^{1,5-7}$ Surgical treatment reduces the incidences of morbidity and mortality caused by femoral neck fractures. In stable fractures, fixation with screws is often possible, preserving the femoral head. However, unstable fractures are generally treated with total or partial arthroplasty of the hip. ${ }^{1,2,4-6.8}$

In most patients with fractures that are not diverted from the femoral neck, internal fixation is the treatment of choice. ${ }^{1}$ These surgeries

All authors declare no potential conflict of interest related to this article. 
that preserve the femoral head cause less damage to the delicate vascularization of this structure. Consequently, a frequent doubt is whether the use of two cannulated screws instead of three is sufficient to provide stability and consolidate the fracture..$^{9,10}$

The main complications of osteosynthesis in femoral neck fractures are fixation failure and pseudoarthrosis. Pseudoarthrosis is more common and occurs in $6 \%$ of cases on average, accounting for $60 \%$ of the complications in this type of fracture. , $^{1,7,711}$

Many studies have compared various types of fixation for unstable fractures, ${ }^{1,5}$ but few present the results with analysis of stable fractures and their variables using the classic fixation techniques described in the literature. , $^{10}$

This study therefore compares the mechanical resistance of femoral neck fixation in synthetic pre-osteotomized bones which simulate a Pauwels type II fracture using two parallel screws and three screws in an inverted pyramid configuration.

\section{MATERIALS AND METHODS}

Ten synthetic proximal femur bones produced in Brazil were used. The bones were produced of rigid polyurethane, with a $7 \mathrm{~mm}$ diameter medullary canal and natural curvature. Specimens were divided into two groups, $\mathrm{A}$ and $\mathrm{B}$.

Group A consisted of five intact specimens of these synthetic models. Using fluoroscopy, three guide wires were introduced in an inverted pyramid arrangement (with the peak of the pyramid in the lower part of the femoral neck and the other two holes above and parallel to each other, one in the anterior portion of the femoral neck and the other in the posterior portion). After confirmation of proper placement with the aid of guide wires, the holes were drilled with a $4.0 \mathrm{~mm}$ bit. Group B was also comprised of five intact synthetic femur bones. In this group, two guide wires were introduced with a parallel guide, with one wire in the center of the femoral neck in the AP and lateral views and the other vertically parallel below the first.

The guide wires were then removed and an osteotomy was performed perpendicular to the axis of the femoral neck with a bone saw in the middle third of the bone, representing a Pauwels type II fracture, (Figure $1 \mathrm{~A}$ and $\mathrm{B}$ ) after marking with a goniometer to make sure there were no differences between the tested specimens. The osteotomy in group A was fixed with three cannulated $7.0 \mathrm{~mm}$ steel screws in the holes which had been drilled previously, in the following order: inferior, anterior and, finally, posterior, as described by Asnis. ${ }^{12}$ In group $B$, the osteotomy was fixed with two cannulated screws. In both groups, the holes were drilled prior to completing the osteotomy in the synthetic bones to facilitate anatomical reduction and compression of the fracture.

After the placement of all screws, X-rays were taken in the AP and lateral planes to evaluate fracture reduction and screw position (35 kV, $100 \mathrm{~mA}, \mathrm{mAs} 3.00$, time 0.030s). (Figure 2A, B, C and D) Mechanical testing of the different femoral neck fracture fixation was then performed using axis compression resulting from the hip compression load according to Pauwels. Compression was created using a Contenco I-3001-C model manual digital hydraulic press (São José da Lapa, MG, Brazil). (Figure 3) until the synthesis failed. Failure was considered to occur when the synthetic bone fractured or a shear fracture larger than $5 \mathrm{~mm}$ occurred. (Figures $4 \mathrm{~A}$ and $\mathrm{B}$ ) The statistical method used was the T-test and post hoc analysis to compare the maximum force $(\mathrm{N})$ between groups $\mathrm{A}$ and $\mathrm{B}$. The independent mean difference test was chosen due to the due to the small sample size in each group, and statistical significance was established at $5 \%$. Because this study was not a clinical trial, and investigated mechanical fracture fixation without the use of any medication or human or animal tissue, approval was not required from the institutional review board. Similarly, since the study did not involve humans, the informed consent term was not required.
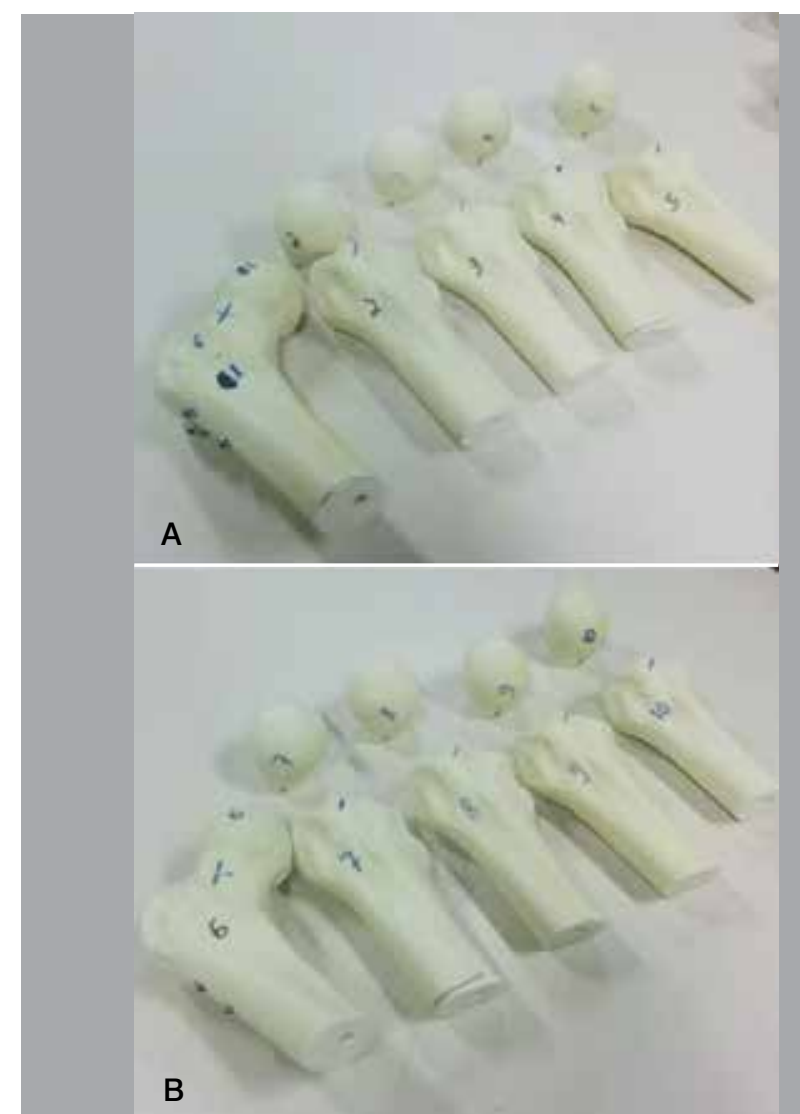

Figure 1. A and B: Samples of group A (fixed with three screws) and B (fixed with two screws).

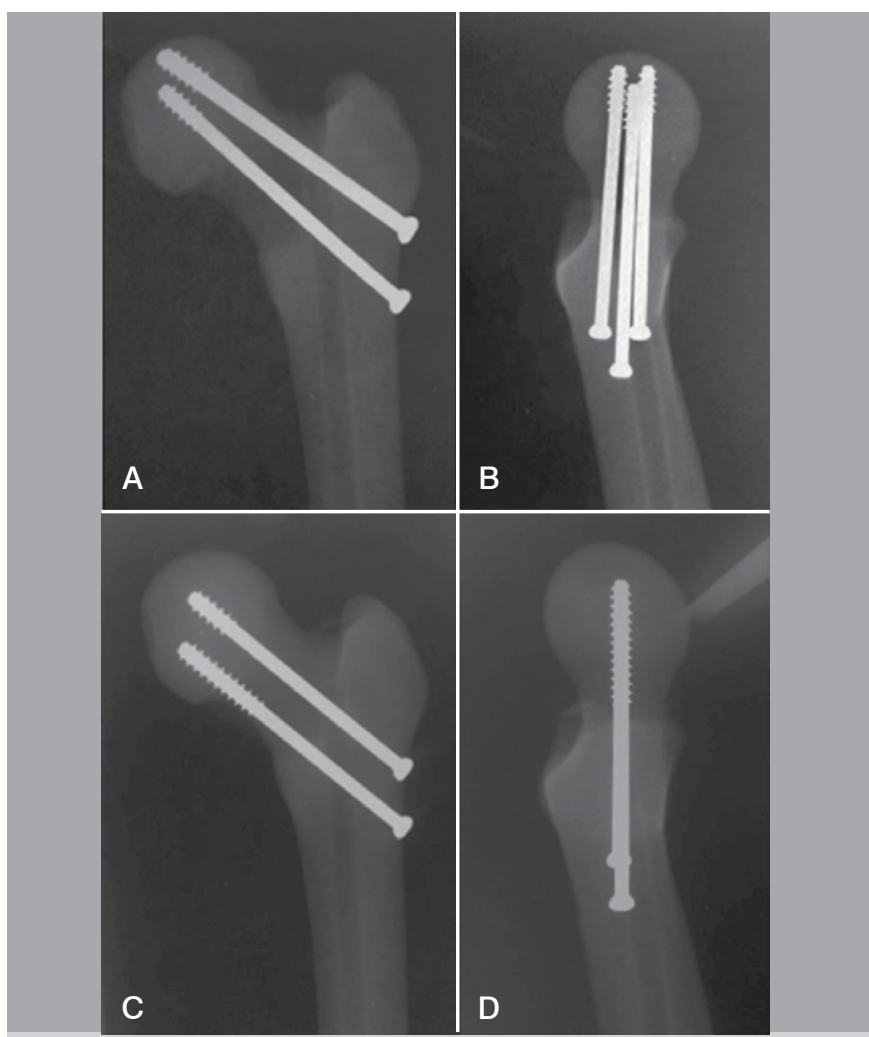

Figure 2. $A, B, C$ and $D$ - Anterior posterior and lateral $X$-ray confirmation of the correct positioning of the screws in groups $A$ and $B$, respectively. 

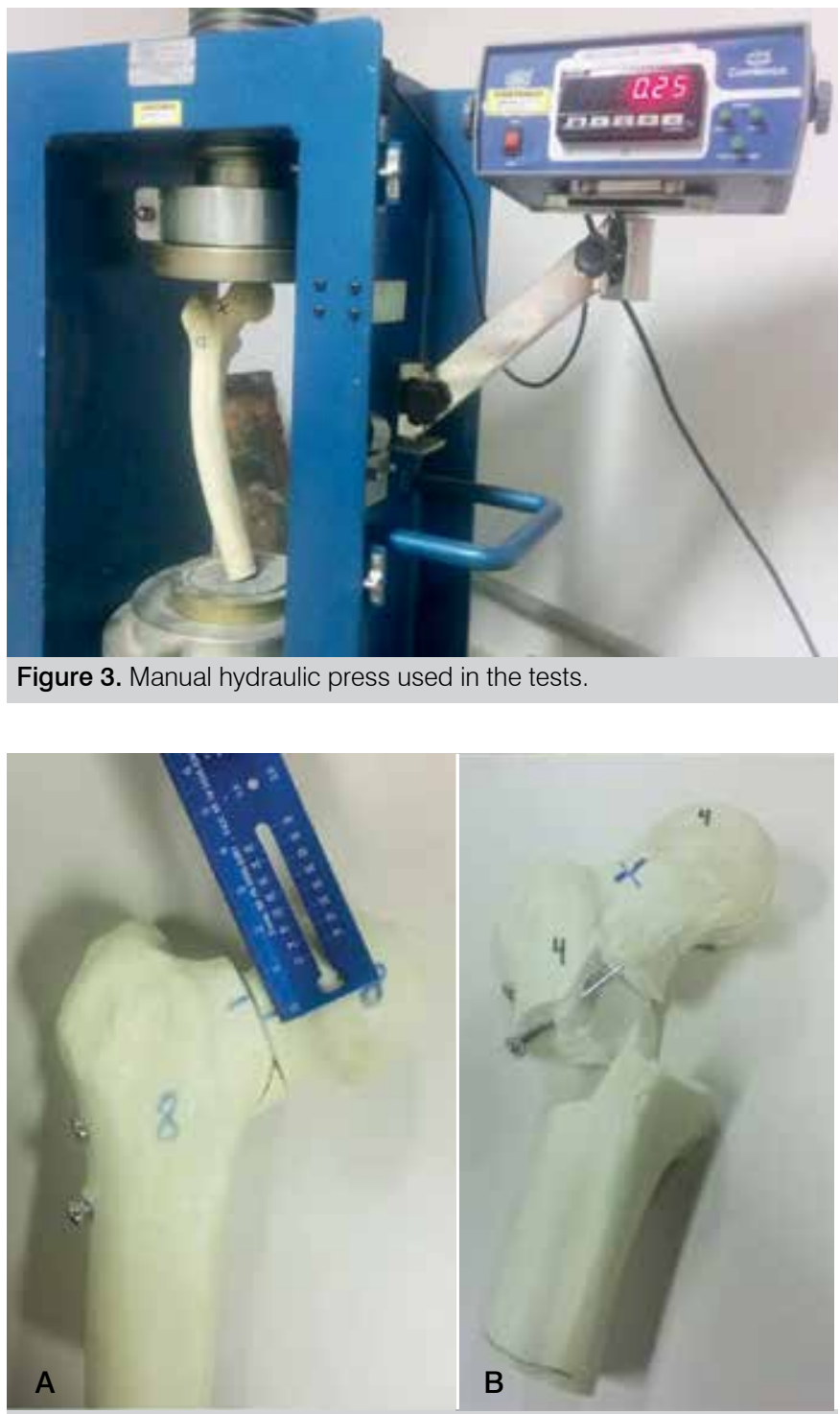

Figure 4. Manual hydraulic press used in the tests.

\section{RESULTS}

In group A (osteosynthesis with three screws), five failures were obtained with the applied load of $530,560,530,490$, and 520 Newtons (N), respectively, for samples 1-5 (mean $526 \mathrm{~N}$, standard deviation $25 \mathrm{~N}$ ). In all cases, the fracture occurred in the transtrochanteric region, with the fracture line in the upper-medial region going toward the lower-lateral region, which Tronzo classified as reverse obliquity fracture (type $\mathrm{V}$ ). There was no shearing in the fracture line which had previously been created in any of the models in this group.

In group B (osteosynthesis with two screws), the load applied until failure was $470,460,450,460$, and $490 \mathrm{~N}$ for samples $6-10$, respectively (mean $466 \mathrm{~N}$, standard deviation $15 \mathrm{~N}$ ). In three cases failure occurred via transtrocanteric fractures (Tronzo type $\mathrm{V}$ ) and two were shear failures larger than $5 \mathrm{~mm}$ in the previously-created transcervical fracture. (Figures $5 \mathrm{~A}$ and $\mathrm{B}$ )

Table 1 presents the values applied to the models in which fixation failure occurred. According to the mean difference test (T-test), group A sustained a significantly higher load until synthesis failure was reached in comparison with group $B$ $(p=0.02)$. (Figure 6)

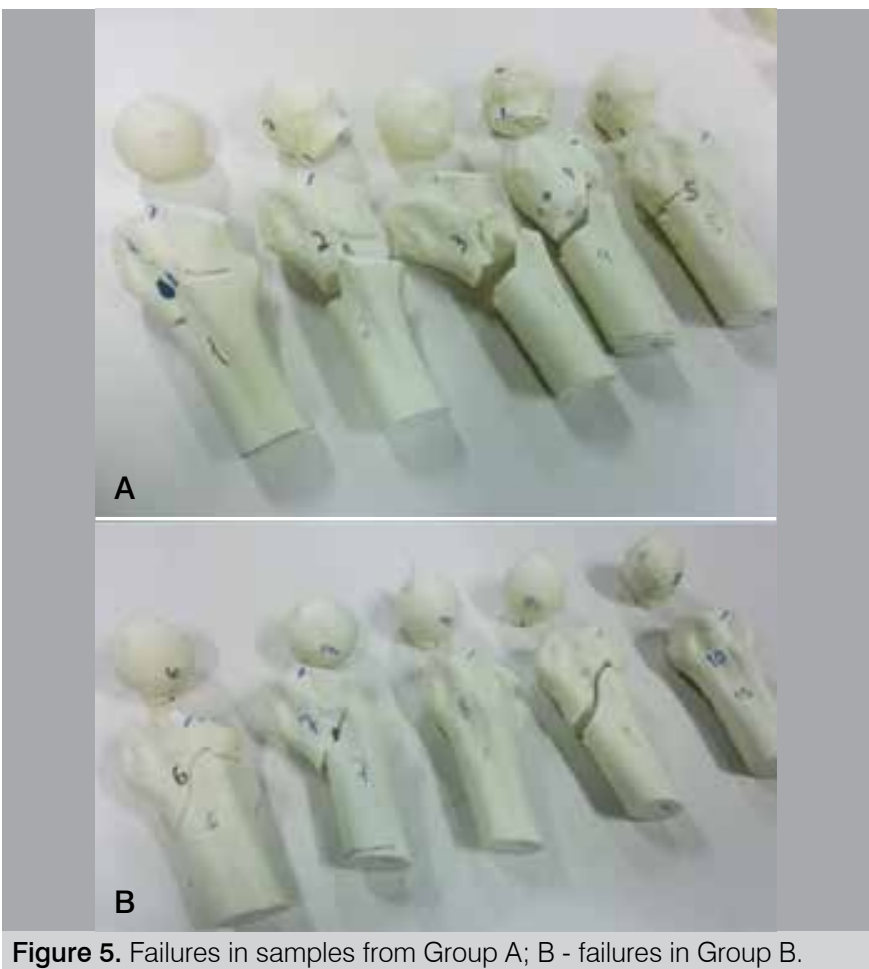

Figure 5. Failures in samples from Group A; B - failures in Group B.

Table 1. Distribution of force in Newtons $(\mathrm{N})$ necessary for the failure of the osteosynthesis.

\begin{tabular}{c|c}
\hline Group A (three screws) & Group B (two screws) \\
\hline 530 & 470 \\
\hline 560 & 460 \\
\hline 530 & 450 \\
\hline 490 & 460 \\
\hline 520 & 490 \\
\hline
\end{tabular}

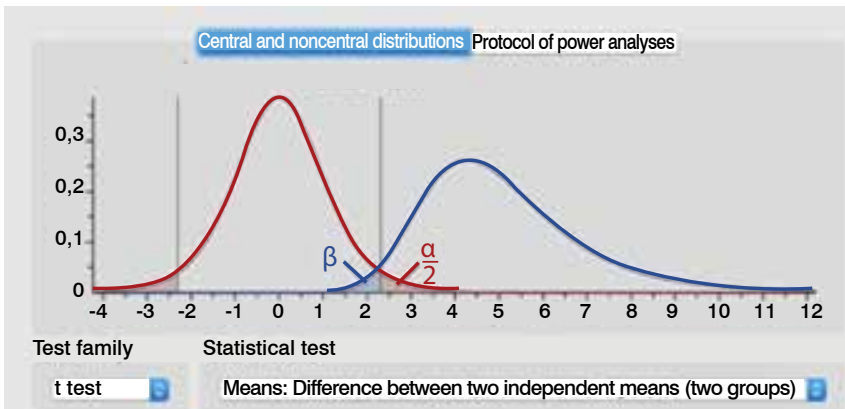

Figure 6. Statistical analysis $T$-test.

\section{DISCUSSION}

The main objective in treating femoral neck fractures is to allow the patient to return to normal activity as soon as possible. ${ }^{5}$ Therefore, the ideal surgical fixation must be capable of withstanding the forces of weight discharge and restrict movement in the fracture focus during bone consolidation. Secure fixation also reduces the high rates of complications reported in treating this type of fracture. ${ }^{1}$

The synthetic bones were chosen to ensure comparable biomechanical properties between the groups and eliminate some variables. ${ }^{13}$ We were consequently able to eliminate some biases inherent to human bones resulting from non-uniform characteristics (bone density, diameter and length) which would complicate the experiment. 
Fixation of femoral neck fractures is often recommended with the use of cannulated screws, which have lower surgical morbidity, cause minimal soft tissue damage and limited blood loss, in addition to providing good stability. The widely accepted technique is the placement of three screws at a low angle (typically $135^{\circ}$ ) in an inverted pyramid arrangement. ${ }^{14,15}$ However, patients who undergo surgical treatment of femoral neck fractures continue to exhibit high mortality (20\%) and a reoperation rate around 35\%. ${ }^{4}$

Selvan et al. ${ }^{16}$ defend the traditional configuration of three screws in the inverted pyramid configuration as the most mechanically stable option in comparison with two or three vertical parallel screws. This can be explained by the fact that the clinical outcome is more related to blood supply to the femoral head after fixation than its actual stability. ${ }^{17,18}$ The AO-ASIF group ${ }^{15}$ also supports the use of three screws, although it does consider fixation with two screws to be an option. In contrast, Krastman et al. ${ }^{9}$ stated that non-diverted femoral neck fractures can be adequately secured with two cannulated screws, and Basile et al. ${ }^{10}$ defended the use of only two screws, stating that although this configuration is less stable, it is sufficient for correct treatment of femoral neck fracture, with a $13.3 \%$ rate of failure for the technique. Basile et al. ${ }^{10}$ also argued that it is difficult to place the implants exactly parallel, and placing the third screw is even more difficult.

In a study using 14 femurs from fresh cadavers, Walker et al. ${ }^{14}$ compared the use of two (parallel horizontal) or three (inverted triangle) cannulated screws and concluded that two screws provided adequate fixation, and that no significant advantage was obtained from the addition of a third screw.

In a prospective study with 268 femoral neck fractures, Lagerby et al. ${ }^{17}$ compared fixation with two screws (Uppsala technique) and three cannulated screws (Richards technique), and in the first year after surgery found a complication rate of $24 \%$ for three screws and $25 \%$ for two screws. Revision procedures with prosthetic replacement occurred in $14 \%$ and $12 \%$ of cases, respectively. The various studies in the literature do not reach a consensus on the number and optimal positioning of the cannulated screws for fixation of femoral neck fractures. The present study agrees with Selvan and the AO-ASIF group in finding that all failures in the three-screw group occurred from fractures in a different site (the transtrochanteric region), without shear stress in the femoral neck fracture, proving the stability of the synthesis. The samples fixed with two screws demonstrated stabilization in the fracture focus, but two failures resulted from shearing. The difference in the results obtained was statistically significant, allowing us to conclude that fixation with three screws is more stable.

We recognize the limitations of our study. The sample size was small, the fractures were simulated by osteotomy, and there are more technologically advanced means to conduct the proposed tests, in addition to the lack of a control group. The use of synthetic bone instead of cadaver bone does not accurately reflect the anatomy of the femoral trabeculae and its support of force, but these synthetic bones were chosen to ensure that the biomechanical properties were comparable between the groups, eliminating variables.

\section{CONCLUSION}

A statistically significant difference was found between the group with Pauwels type II fractures fixed with three screws (group A) and the group secured with two screws (group B) $(p=0.02)$.

Furthermore, no shear failure was seen in transcervical fracture in group A, with all failures occurring due to fractures in the transtrochanteric region, while shear fracture was the source of failure in $40 \%$ of the samples in group B.

AUTHORS' CONTRIBUTIONS: Each author made significant individual contributions to this manuscript. HMG (0000-0001-7527-969X)*: contributed to the drafting, revision, and intellectual concept of the article; RA (0000-0002-1148-3437) ${ }^{\star}$ : contributed to the intellectual concept, drafting, and statistical analysis; AF (0000-0001-6555-8193)* , CBG (0000-0003-2587-5586)*, and MRFR (0000-0002-8737-5010)*: participated in the drafting and revision of the text. All authors approved the final version of the manuscript. *ORCID (Open Researcher and Contributor ID).

\section{REFERENCES}

1. Freitas A, Torres GM, Souza ACAM, Maciel RA, Souto DRM, Ferreira GNB. Análise da resistência mecânica de fixação de fratura do colo femoral em osso sintético com DHS e parafuso antirrotatório. Rev Bras Ortop. 2014;49(6):586-92.

2. Lustosa LP, Bastos EO. Fraturas proximais do fêmur em idosos: qual o melhor tratamento? Acta Ortop Bras. 2009;17(5):309-12.

3. Daniachi D, Netto AS, Ono NK, Guimarães RP, Polesello GC, Honda EK. Epidemiologia das fraturas do terço proximal do fêmur em pacientes idosos. Rev Bras Ortop. 2015;50(4):371-7.

4. Sakaki MH, Oliveira AR, Coelho FF, Leme LEG, Susuki I, Amatuzzi MM. Estudo da Mortalidade na fratura do Fêmur Proximal em idosos. Acta Ortop Bras. 2004; 12(4):242-9

5. Freitas A, Azevedo BAS, Souza RR, Costa HI, Maciel RA, Souto DRM. Análise mecânica na fixação da fratura do colo femoral em osso sintético. Acta Ortop Bras. 2014;22(3):155-8.

6. Neer C, Mclaughlin HL. Intracapsular fractures of the neck of the femur: Follow-up report of 130 patients treated by internal fixation with the Smith-Petersen nail. Am J Surg. 1948;76(5):528-36.

7. Leighton RK. Fractures of the neck of the femur. In: Bucholz RW, Heckman JD, Court-Brown CM (Ed.). Rockwood \& Green's fractures in adults. 6th ed. Lippincott Williams \& Wilkins. p. 1780-81.

8. Freitas A, Lula WF, Oliveira JS, Maciel RA, Souto DRM, Godinho PF. Análise da resistência mecânica na fixação da fratura do colo femoral em osso sintético tipo ASNIS. Acta Ortop Bras. 2014;22(4):206-9.

9. Krastman P, van den Bent RP, Krijnen P, Schipper IB. Two cannulated hip screws for femoral neck fractures: treatment of choice or asking for trouble? Arch Orthop Trauma Surg. 2006;126(5):297-303.

10. Basile R, Pepicelli GR, Takata ET. Osteossíntese da fratura do colo femoral: dois ou três parafusos? Rev Bras Ortop. 2012;47(2):165-8.

11. Parker MJ, Blundell C. Choice of implant for internal fixation of femoral neck fractures. Meta-analysis of 25 randomized trials including 4,925 patients. Acta Orthop Scand. 1998;69(2):138-43.

12. Asnis SE, Wanek-Sgaglione L. Intracapsular fractures of the femoral neck. Results of cannulated screw fixation. J Bone Joint Surg Am. 1994;76(12):1793-803.

13. Cristofolini L, Viceconti M, Cappello A, Toni A. Mechanical validation of whole bone composite femur models. J Biomech. 1996;29(4):525-35.

14. Walker E, Mukherjee DP, Ogden AL, Sadasivan KK, Albright JA. A biomechanical study of simulated femoral neck fracture fixation by cannulated screws: effects of placement angle and number of screws. Am J Orthop. 2007;36(12):680-4.

15. Ruedi TP, Buckley RE, Moran CG. AO Principles of Fracture Management. New York: Thieme; 2000.

16. Selvan VT, Oakley MJ, Rangan A, AI-Lami MK. Optimum configuration of cannulated hip screws for the fixation of intracapsular hip fractures: a biomechanical study. Injury. 2004;35(2):136-41.

17. Lagerby M, Asplund S, Ringqvist I. Cannulated screws for fixation of femoral neck fractures: no difference between Uppsala screws and Richards screws in a randomized prospective study of 268 cases. Acta Orthop Scand. 1998;6(4):387-91.

18. Klenerman L, Marcuson RW. Intracapsular fractures of the neck of the femur. J Bone Joint Surg Br. 1970;52(3):514-7 